\title{
HUBUNGAN KEPADATAN ANOPHELES SP. DENGAN KEJADIAN MALARIA DI DESA BONTOSUNGGU KABUPATEN KEPULAUAN SELAYAR
}

\author{
Risky ${ }^{1}$, Muhammad Hasan ${ }^{2}$ \\ ${ }^{1}$ Alumni Jurusan Kesehatan Masyarakat Fakultas Kesehatan Masyarakat Universitas Muslim \\ Indonesia Makassar \\ ${ }^{2}$ Widyaiswara pada Balai Besar Pelatihan Kesehatan Makassar
}

\begin{abstract}
ABSTRAK
Malaria merupakan suatu penyakit yang disebabkan oleh protozoa dari genus plasmodium yang ditularkan melalui gigitan nyamuk Anopheles betina serta dapat juga ditularkan secara langsung melalui transfusi darah, jarum suntik serta ibu hamil kepada bayinya. Terdapat empat spesies Plasmodium yaitu P. falcifarum, P. vivax, P. malariae, dan P. ovale. Penelitian bertujuan untuk mengetahui hubungan kepadatan nyamuk Anapholes sp dengan kejadian malaria di desa Bontosunggu Kab. Kepulauan Selayar tahun 2013. Penelitian dilakukan secara Observasional dengan pendekatan cross sectional study. Observasi Anopheles sp. dengan penangkapan nyamuk malam hari dengan umpan manusia (HLC), sedangkan penemuan penderita malaria menggunakan kit RDT (Rapid Diagnostic Test) bantuan Global Foundation (GF). Anopheles yang ditangkap dari hasil penangkapan malam hari dengan metode HLC diidentifikasi sebagai An. subpictus dan An.barbirostris. Angka kepadatan per jam penangkapan (MHD) An. Subpictus, tertinggi pada jam 22.00 sebesar 0,083. MHD An. Barbirostris sebesar 0,016 pada masing-masing jam 23.00 dan 24.00. Ditemukan 3 orang (7,1\%) Penderita Malaria melalui RDT dari 42 orang sampel. Analisis bivariat menunjukkan ada hubungan antara kepadatan Anopheles sp. dengan kejadian malaria dengan nilai $\mathrm{p}=0,032<0,05$. Analisis bivariat juga menunjukkan adanya hubungan antara keberadaan plasmodium dengan kejadian malaria dengan nilai $\mathrm{p}=0,000<0,05$.
\end{abstract}

Kata kunci: Anopheles sp., Malaria, Analisis Bivariat.

\section{PENDAHULUAN}

Penyakit malaria di Kab. Selayar disinyalir berkorelasi dengan kepadatan nyamuk Anopheles sebagai vektor, sebagaimana pernyataan Rozendal (1997) bahwa banyaknya vektor akan berkorelasi positif dengan tingginya kasus penyakit. Kepadatan populasi vektor yang tinggi dapat meningkatkan kontak vektor yang infektif terhadap manusia (Mc. Kelvey et al. 1991).

Kepadatan vektor menjadikan Kab. Selayar menjadi daerah endemis malaria. Kabupaten Selayar secara geografis terletak di jazirah selatan Propinsi Sulawesi.

Daerah endemis, penduduknya dapat terinfeksi malaria berulang kali karena itu pada saat berumur dewasa dapat menjadi kebal. Sebaliknya pada penduduk dengan status pendatang yang berasal dari daerah yang bebas malaria sangat mudah terkena penyakit malaria. Beberapa faktor yang dapat mempengaruhi endemisitas malaria antara lain faktor lingkungan, pelayanan kesehatan, sosial, ekonomi dan budaya. Faktor lain adalah kontribusi genetis dan etnis dari penduduk yang berbeda dan bervariasi sesuai karakteristik demografi. Perubahan lain adalah variasi kultural terjadi dalam kebiasaan, pekerjaan, higiene perorangan dan bahkan persepsi tentang sakit dan sehat serta faktor tersedianya pelayanan kesehatan.

\section{METODOLOGI}

\section{Jenis Penelitian}

Jenis penelitian ini merupakan penelitian observasional dengan pendekatan cross sectional study. Penelitian ini dimaksudkan untuk melihat hubungan keberadaan nyamuk anopeles dengan kejadian malaria

\section{Lokasi Penelitian}

Lokasi penelitian dilakukan di Desa Bontosunggu Kabupaten Selayar Propinsi Sulawesi Selatan

\section{Populasi dan Sampel}

Populasi dalam penelitian ini adalah warga yang sakit dan tidak sakit berjumlah 42 di Desa Bontosunggu Kab. Kepulauan Selayar . Sampel pada penelitian ini adalah sebagian dari penduduk baik yang menderita maupun yang tidak menderita malaria, adapun pengambilan sampel dengan cara purposive 
sampling dengan kriteria jarak rumah dalam radius 100 meter dan pengambilan sampel di Desa Bontosunggu yaitu dengan propotinal sampling dengan mengidentifikasi tempat berkembangbiakanya nyamuk dan rumah penderita.

\section{Instrumen}

Instrumen yang dipakai dalam penelitian ini berupa lembar observasi, peralatan survey serta peralatan laboratorium lapangan sebagai berikut :RDT,Kapas alkohol,Kasa steril, Lanset steril, Kapas kering,Loop Imicro capiler tube,Cairan buffer, Microskop,Lebel, Senter

\section{Pengumpulan Data}

\section{Data Primer}

Data primer diperoleh dari data identifikasi di lapangan baik berupa mengidentifikasi nyamuk dewasa dari hasil HLC, pengukuran titik koordinat tempat berkembangbiaknya nyamuk dan melihat dari Lab. Hasil sediaan darah masyarakt di Desa Bontosunggu.

\section{Data Sekunder}

Pengambilan data sekunder berupa data RDT, peta administrasi kota, kondisi geografis, data malaria dikumpulkan dari instansi terkait seperti badan pemberantasan penyakit menular, BPS, Dinas Kesehatan Propinsi maupun Dinas Kesehatan Kab. Selayar.

\section{Analisis Data}

Analisi data dilakukan dengan uji hipotesis nol dengan tingkat kemaknaan dipakai adalah $\alpha=0,05$ dan mengukur parameter angka kepadatan nyamuk yang menggigit orang. Banyaknya nyamuk anopheles yang menggigit orang per spesies per jam, di peroleh dengan cara perhitungan sebagai berikut :

jumlah nyamuk tertangkap per spesies

Jumlah jam penangkapan X lamanya (jam) X jumlah inang

\section{HASIL}

Analisis Univariat

a. keberadaan nyamuk

1. Keberadaan nyamuk anopheles

Tabel 1

Distribusi keberadaan nyamuk anopheles di Desa Bontosunggu Kab.Selayar tahun 2013

\begin{tabular}{|c|c|c|}
\hline Jam penangkapan & In & Out \\
\cline { 2 - 3 } & 0 & 0 \\
$18.00-19.00$ & 0 & 0 \\
$19.00-20.00$ & 0 & 1 \\
$20.00-21.00$ & 0 & 2 \\
$21.00-22.00$ & 0 & 5 \\
$22.00-23.00$ & 1 & 1 \\
$23.00-24.00$ & 0 & 1 \\
$24.00-01.00$ & 0 & 1 \\
$01.00-02.00$ & 0 & 2 \\
$02.00-03.00$ & 0 & 0 \\
$03.00-04.00$ & 0 & 0 \\
$04.00-05.00$ & 0 & 0 \\
$05.00-06.00$ & & \\
\hline
\end{tabular}

Sumber: Data primer 
Berdasarkan tabel 1. menunjukkan bahwa keberadaan nyamuk di Desa Bontosunggu berdasarkan dari hasil HLC dberjumlah 14 (7.1\%) ekor. pada saat HLC pukul 18.00 - 20.00 dari umpan orang baik di dalam rumah maupun di luar rumah tidak ada ditemukan, pukul 20.00 - 21.00 baru ada ditemukan nyamuk yaitu 1 ekor, pada pukul 21.00 - 22.00 ditemukan juga 2 ekor dengan menggunakan umpan orang di luar rumah, pukul 22.00 - 23.00 merupaka puncak menggigitnya dilihat dari banyaknya nyamuk yang di dapat yaitu 5 ekor. Pada pukul 23.00 - 24.00 baru ada di dapat 1 ekor di dalam rumah dan 1 ekor di luar rumah dengan umpan orang, pukul 24.00 - 01.00 dengan umpan orang di luar rumah di dapat 1 ekor,pukul $01.00-02.00$ juga di dapat 1 ekor dan pukul $02.00-03.00$ didapat 2 ekor.

Table 2.

Keberadaan Spesies Nyamuk Anopheles Yang Ditangkap Di Dalam Rumah Dan Diluar Rumah Di Desa Bontosunggu Kab. Kepulauan Selayar Tahun 2013.

\begin{tabular}{|c|c|c|c|c|}
\hline \multicolumn{5}{|c|}{ Spesies nyamuk anopheles } \\
\hline Jam penengkapan & $\begin{array}{c}\text { Anopheles } \\
\text { Barbirostrid }\end{array}$ & \multicolumn{2}{c|}{ Anopheles Subpictus } \\
\cline { 2 - 5 } & UOD & UOL & OUD & UOL \\
\hline $18.00-19.00$ & 0 & 0 & 0 & 0 \\
$19.00-20.00$ & 0 & 0 & 0 & 0 \\
$20.00-21.00$ & 0 & 0 & 0 & 0,016 \\
$21.00-22.00$ & 0 & 0 & 0 & 0,033 \\
$22.00-23.00$ & 0 & 0 & 0 & 0,083 \\
$23.00-24.00$ & 0 & 0,016 & 0,016 & 0 \\
$24.00-01.00$ & 0 & 0,016 & 0 & 0 \\
$01.00-02.00$ & 0 & 0 & 0 & 0,016 \\
$02.00-03.00$ & 0 & 0 & 0 & 0,033 \\
$03.00-04.00$ & 0 & 0 & 0 & 0 \\
$04.00-05.00$ & 0 & 0 & 0 & 0 \\
$05.00-06.00$ & 0 & 0 & 0 & 0 \\
\hline
\end{tabular}

Sumber: data primer

Nyamuk Anopheles subpictus belum ada ditemukan pada pukul 18.00 - 20.00 di Desa Bontosunggu, rata - rata puncak menggigitnya mulai pukul $20.00-03.00$. umpan di luar rumah baru ada ditemukan 1 ekor pada 20.00-21.00, 2 ekor pada pukul 21.00 - 22.00, 5 ekor pada pukul $22.00-$ 23.00,umpan di dalam rumah juga detemuka 1 ekor pada pukul $23.00-24.00$, 1 ekor pada pukul $01.00-02.00,2$ ekor pada pukul $02.00-03,00$.

Nyamuk Anopheles Barbirostris baru ada diteukan 1 ekor pada pukul 23.00 - 24.00 dengan umpan orang di luar rumah,dan 1 ekor pada pukul $24.00-01.00$ juga dengan umpan orang di luar rumah.
Nyamuk Anopheles barbirostis aktif menggigit orang sepanjang malam.pada pukul 23.00-01.00 nyamuk ini biasanya di luar rumah, nyamuk Anopheles. Subpictus aktifitasnya menggigit pada malam hari Cuma sebagian kecil di dalam rumah kebanyakan di dapat di luar rumah dengan puncak menggigitnya pada pukul 20.00-03.00.

Nyamuk Anopheles barbirostis sangat kecil jumlahnya (Gambar 4). jumlah yang didapat hanya 2 ekor dibanding dengan nyamuk Anopheles Subpictus jumlahnya cukup banyak sekitar 12 ekor dengan suhu berkisar antara $25^{\circ} \mathrm{C}-29^{\circ} \mathrm{C}$. 
2. Kejadian malaria

Tabel 3.

Distribusi kejadian malaria berdasarkan hasil RDT di Desa Bontosunggu Kab.Selayar

tahun 2013.

\begin{tabular}{|c|c|c|}
\hline Kejadian malaria & N & Persen \\
\hline Ada & 3 & $7.1 \%$ \\
\hline Tidak ada & 39 & $92.9 \%$ \\
\hline Total & 42 & $100 \%$ \\
\hline
\end{tabular}

sumber: data skunder

Berdasarkan Tabel 3. menunjukkan bahwa jumlah Penderita sesui dengan hasil RDT berjumlah 3 (7.1\%) respondent dari $42 \quad(100 \%)$ sampel.dengan hasil RDT yang didapat cuma positif penyakit malaria yang kasus lokal saja yang di ambil,namun ada beberapa yang positif malaria akan tetapi kasus inpor jadi tidak di masukan dalam penelitian.

3. Keberadaan plasmodium

Tabel 4.

Distribusi keberadaan plasmodium di Desa Bontosunggu Kab.Selayar tahun 2013.

\begin{tabular}{|c|c|c|}
\hline Keberadaan plasmodium & $\mathbf{N}$ & Persen \\
\hline Ada & 3 & $7.1 \%$ \\
\hline Tidak ada & 39 & $92.9 \%$ \\
\hline Total & 42 & $100 \%$ \\
\hline
\end{tabular}

Sumber :data skunder

Berdasarkan Tabel 4. menunjukkan bahwa jumlah Sampel yaitu $42(100 \%)$ respondent yang positif ada $3(7.1 \%)$ respondent sampel sedangkan yang $39(92.9 \%)$ didapatkan negatif dari sampel yang didapat dari kasus lokal cuma ada 3 (7.1\%) respondent yang positif mengandung lasmodium, sedangkan sampel yang negatif tidak mengandung plasmodium ada 39 $(92.9 \%)$ respondent. 


\section{Analisis Bivariat}

a. Hubungan keberadaan nyamuk dengan kejadian malaria di Desa Bontosunggu

Tabel 7.

Hubungan keberadaan nyamuk dengan kejadian malaria di Desa Bontosunggu Kabupaten Kepulauan Selayar Tahun 2013.

\begin{tabular}{|l|l|l|l|l|l|l|l|}
\hline \multirow{2}{*}{$\begin{array}{l}\text { Keberadaan } \\
\text { nyamuk }\end{array}$} & \multicolumn{3}{|l|}{ Kejadian malaria } & Total & $\%$ & P \\
\cline { 2 - 6 } & \multicolumn{2}{|l|}{ Menderita } & \multicolumn{2}{l|}{ Tidak menderita } & & & \\
\cline { 2 - 7 } & $\mathrm{N}$ & $\%$ & $\mathrm{~N}$ & $\%$ & & & \\
\hline Ada & 3 & 21.4 & 11 & 78.6 & 14 & 100 & 0,032 \\
\hline Tidak ada & 0 & 0.0 & 28 & 100 & 28 & 100 & \\
\hline Total & 3 & 7.1 & 39 & 92.9 & 42 & 100 & \\
\hline
\end{tabular}

Sumber : data primer 2013

Berdasarkan Tabel 7. menunjukkan bahwa hubungan keberadaan nyamuk dengan kejadian malaria di Desa Bontosunggu bahwa jumlah yang positif menderita $3(21.4 \%)$ respondent dan jumlah negatif tidak menderita berjumlah $39(92.6 \%)$ respondent.

Keberadaan nyamuk berdasarkan hasil HLC yang dilakukan dengan umpan orang di luar dan di dalam rumah, malam hari sebanyak 6 orang 3 di dalam rumah dan 3 di luar rumah.sedangkan 4 orang untuk mengidentifikasi nyamuk dari hasil yang ditangkap.nyamuk yang hinggap langsung ditangkap dengan menggunakan aspirator.waktu penangkapan dilakukan pada pukul 18.00 - 06.00,penangkapan dilakukan selama 40 menit setiap jam, sekitar kandang ternak selama 10 menit setiap jam, di sekitar tambak selama 10 menit setiap jam dan 10 menit untuk identifikasi.untuk mengetahuai kepadatannya populasi nyamuk dihitung sesuai dengan metoda.

Penangkapan nyamuk juga di lakukan pagi hari selama 20 menit, diduga sebagai tempat di dalam rumah, tempat istirahat, tebing sungai dan tambak. semua hasil tangapan di masukan ke dalam peper cup yang di beri label (lokasi,jam dan tempat penangkapan), ditutup kain kasa dengan di ikat karet gelang. Kemudian nyamuk di bius sampai pingsan untuk proses identifikasi.

Dari hasil penangkapan yang didapat kemudian di uji statistic dari sampel iyaitu nilai $\mathrm{p}$ $=0,032<0,05$ sehingga Ha diterima (bermakna) atau ada hubungannya antara keberadaan nyamuk dengan kejadian malaria. 
b. Hubungan keberadaan plasmodium dengan kejadian malaria di Desa bontosunggu

Tabel 8.

Hubungan keberadaan plasmodium dengan kejadian malaria di Desa Bontosunggu Kabupaten

Kepulauan Selayar

Tahun 2013.

\begin{tabular}{|c|c|c|c|c|c|c|c|}
\hline \multirow{3}{*}{$\begin{array}{l}\text { Keberadaan } \\
\text { plasmodium }\end{array}$} & \multicolumn{4}{|c|}{ Kejadian malaria } & \multirow[t]{3}{*}{ Total } & \multirow[t]{3}{*}{$\%$} & \multirow[t]{3}{*}{$\mathrm{P}$} \\
\hline & \multicolumn{2}{|c|}{ Menderita } & \multicolumn{2}{|c|}{ Tidak menderita } & & & \\
\hline & $\mathrm{N}$ & $\%$ & $\mathrm{~N}$ & $\%$ & & & \\
\hline Positif & 3 & 100 & 0 & 0.0 & 3 & 100 & 0.000 \\
\hline Negative & 0 & 0.0 & 39 & 100 & 39 & 100 & \\
\hline Total & 3 & 7.1 & 39 & 92.9 & 42 & 100 & \\
\hline
\end{tabular}

Sumber : data primer

Berdasarkan Tabel 8. menunjukkan bahwa hubungan keberadaan plasmodium dengan kejadian malaria di Desa Bontosunggu bahwa jumlah yang positif menderita $3(21.4 \%)$ respondent dan jumlah negative tidak menderita berjumlah 39 (92.6\%) respondent.

Pengambilan sampel darah di lakukan dengan menggunakan RDT,yang menjadi sampel dalam pengambilan sedian darah iyaitu warga yang sakit. Setelah darah warga di ambil dengan alat RDT kemudian di bawa ke Lab. Puskemas Bontosunggu untuk di lihat positif atau negative.

Dari hasil RDT yang di uji statistic dari sampel diperoleh nilai $\mathrm{p}=0,000<0,05$ atau bermakna sehingga diterima Ha dengan kesimpulan bahwa terdapat hubungan antara keberadaan plasmodium dengan kejadian malaria.

\section{DISKUSI}

Penelitian hubungan keberadaan nyamuk dengan kejadian malaria di Desa Bontosunggu yang telah dilakukan pada Bulan Maret 2013. Desain penelitian case control digunakan sebagai panduan arah pengumpulan data dari 42 sampel. Penentuan kasus malaria berdasarkan data malaria positif yang diperiksa pada laboratorium di Puskesmas Bontosunggu.

Penyakit malaria adalah penyakit menular yang menyerang dalam bentuk infeksi akut ataupuan kronis. Penyakit ini disebabkan oleh protozoa genus plasmodium bentuk aseksual, yang masuk ke dalam tubuh manusia dan ditularkan oleh nyamuk Anopheles betina.

Dari 2 variabel idependent yang dianalis secara bivariat didapatkan semua variabel dinyatakan potensial ada hubungannya dengan kejadian malaria. Untuk melihat hubungan keberadaan nyamuk anopheles dengan kejadian malaria akan dibahas dalam uraian dibawah ini:

\section{Hubungan kenberadaan nyamuk} anopheles $s p$ dengan kejadian malaria

Penyakit malaria adalah salah satu penyakit yang penularannya melalui gigitan nyamuk anopheles betina. Berdasarkan survey unit kerja SPP (serangga penular penyakit) telah ditemukan di Indonesia ada 46 species nyamuk anopheles yang tersebar diseluruh Indonesia. Dari species-species nyamuk tersebut ternyata ada 20 species yang dapat menularkan penyakit malaria.

Habitat nyamuk ditemukan di Desa Bontosunggu yang letaknya di pinggir tambak, di pinggir sungai dengan permukaan banyak di tumbuhi oleh lumut dan serpihan daun. Tambak dan sungai tersebut sangat potensial sebagai habitat perkembangbiakan nyamuk.

Dari penangkapan nyamuk di Desa Bontosunggu Kabupaten Kepulauan Selayar ditemukan 2 spesies nyamuk Anopheles yaitu Anopheles Barbirostris, Anopheles. Subpictus. Selama penelitian dilakuka di Desa Bontosunggu Kabupaten Kepulauan 
Selayar nyamuk subpictus yang paling banyak di temukan di luar rumah, ada beberapa nyamuk subpictus di dapat di sekitar kandang ternak yang kemungkinan besar menyukai darah binatang daripada manusia, akan tetapi bila ternak sedikit maka nyamuk akan mencari sumber darah manusia. nyamuk barbiristris tidak ada ditemukan di dalam rumah namun yang di dapat hanya ada di luar rumah,nyamuk barbirostris lebih sedikit di banding dengan subpictus.

Dari hasil penangkapan di Desa Bontosunggu yang di mulai pada pukul 18.00 - 20.00 dengan umpan orang, baik di dalam rumah maupun di luar rumah tidak ada ditemukan, pukul 20.00 - 21.00 baru ada ditemukan nyamuk yaitu 1 ekor, pada pukul 21.00 - 22.00 ditemukan juga 2 ekor dengan menggunakan umpan orang di luar rumah, pukul 22.00 - 23.00 merupakan puncak menggigitnya dilihat dari banyaknya nyamuk yang di dapat yaitu 5 ekor. Pada pukul 23.00 - 24.00 baru ada di dapat 1 ekor di dalam rumah dan 1 ekor di luar rumah dengan umpan orang, pukul 24.00 - 01.00 dengan umpan orang di luar rumah di dapat 1 ekor, pukul 01.00 - 02.00 juga di dapat 1 ekor dan pukul $02.00-03.00$ didapat 2 ekor.

Nyamuk Anopheles subpictus belum ada ditemukan pada pukul $18.00-20.00$ di Desa Bontosunggu, rata - rata puncak menggigitnya mulai pukul 20.00 - 03.00 . umpan di luar rumah baru ada ditemukan 1 ekor pada 20.00-21.00, 2 ekor pada pukul 21.00 - 22.00, 5 ekor pada pukul $22.00-$ 23.00,umpan di dalam rumah juga detemuka 1 ekor pada pukul 23.00 - 24.00, 1 ekor pada pukul $01.00-02.00,2$ ekor pada pukul 02.00 $-03,00$.

Nyamuk Anopheles Barbirostris baru ada diteukan 1 ekor pada pukul 23.00 24.00 dengan umpan orang di luar rumah,dan 1 ekor pada pukul $24.00-01.00$ juga dengan umpan orang di luar rumah.

Nyamuk Anopheles barbirostis aktif menggigit orang sepanjang malam.pada pukul 23.00-01.00 nyamuk ini biasanya di luar rumah, nyamuk Anopheles. Subpictus aktifitasnya menggigit pada malam hari Cuma sebagian kecil di dalam rumah kebanyakan di dapat di luar rumah dengan puncak menggigitnya pada pukul 20.0003.00.

Nyamuk Anopheles barbirostis sangat kecil jumlah yang didapat hanya 2 ekor dibanding dengan nyamuk Anopheles Subpictus jumlahnya cukup banyak sekitar 12 ekor dengan suhu berkisar antara $25^{\circ} \mathrm{C}-29^{\circ}$ C.

Keadaan aktifitas nyamuk yang mulai menggigit dan puncak kepadatan pada malam hari, akan sangat mendukung terjadinya kontak antara nyamuk dengan manusia sehingga dapat meneyebabkan penularan. Karena pada malam hari : kemungkinan banyak masyarkat yang masih berada di luar rumah samapi larut malam, karena kebanyakan masyarakat Desa Bontosunggu aktifitasnya lebih banyak pada malam hari.panjang umur nyamuk sangat berpengaruh terhadap perkembangan plasmodium stadium sporozoit di dalam tubuh nyamuk.

Sehingga hasil dari penagkapan yang di dapat sekitar 14 ekor dapat diuji statistic dari sampel diperoleh nilai $\mathrm{p}=0,032<$ 0,05 sehingga $\mathrm{Ha}$ diterima atau ada hubungannya antara keberadaan nyamuk dengan kejadian malaria, namun dapat di katakan bahwa jumlah nyamuk yang di dapat tidak terlalu padat sesuai dengan hasil olah data dari format metoda yang ditentukan.

\section{Hubungan keberadaan plasmodium dengan kejadian malaria}

Malaria adalah penyakit infeksi parasit yang disebabkan oleh plasmodium yang menyerang eritrosit dan ditandai dengan ditemukannya bentuk aseksual didalam darah. Infeksi malaria memberikan gejala berupa demam, menggigil, anemia dan splenomegali. Dapat berlangsung akut ataupun kronik. Infeksi malaria dapat berlangsung tanpa komplikasi ataupun mengalami komplikasi sistemik yang dikenal sebagai malaria berat. Sejenis infeksi parasit yang menyerupai malaria ialah infeksi babesiosa yang menyebabkan babesiosis ( Sudoyo, dkk 2006).

Pengambilan sampel darah di lakukan dengan menggunakan RDT,yang menjadi sampel dalam pengambilan sedian darah iyaitu warga yang sakit. Setelah darah warga di ambil dengan alat RDT kemudian di bawa ke Lab. Puskemas Bontosunggu untuk di lihat positif atau negative.

Berdasarkan hasil RDT yang di uji statistic dari sampel diperoleh nilai $p=0,000<$ 0,05 atau bermakna sehingga kesimpulannya terdapat hubungan antara keberadaan 
plasmodium dengan kejadian malaria dari sampel yaitu $42(100 \%)$ yang positif ada 3 (7.1\%) sampel sedangkan yang $39(92.9 \%)$ di dadapatkan negatif .

Penelitian tentang hubungan keberadaan nyamuk anopheles sp dengan kejadian malaria yang telah dilakukan pada Bulan Maret tahun 2013. Desain penelitian cros cectional digunakan sebagai panduan arah pengumpulan data yang dilakukan di Desa Bontosunggu. Penentuan kasus malaria berdasarkan data malaria yang di dapat di Puskesmas Bontosunggu selama tahun 2013.

\section{KESIMPULAN}

1. Ditemukan positif nyamuk Anopheles pada rumah penderita dan bukan di rumah penderita.

2. Ditemukannya juga nyamuk anopheles $s p$ pada sekitar rumah warga baik didalam rumah maupun diluar rumah,namun lebih banyak ditemukan di luar rumah.

3. Ada kecendrungan/trend distribusi tempat $H L C$ positif nyamuk Anopheles berada pada tempat (rumah warga) dengan kasus yang ditemukan.

4. Ditemukannya plasmodium pada warga yang pada saat melakukan HLC ditemukan nyamuk anopheles $s p$.

\section{UCAPAN TERIMAKASI}

1. Bapak Kepala Desa Bontosunggu

Kabupaten Kepulauan Selayar

2. Bapak Dekan Fakultas Kesehatan

Masyarakat Universitas Muslim

Indonesia

3. Bapak Isra Wahid Kepala

Laboratorium Entomologi FK UNHAS

\section{DAFTAR PUSTAKA}

Dahlan, Sopiyudin. 2011. Statistik untuk Kedokteran dan Kesehatan. Jakarta : Salemba Medika.

Daud, A., Anwar, dan Ruslan. 2003. DasarDasar Kesehatan Lingkungan. Makassar : Jurusan Kesehatan Lingkungan FKM Unhas.

Darmadi. 2002. Hubungan Kondisi Fisik Rumah dan Lingkungan Sekitar Rumah serta Praktik Pencegahan dengan Kejadian Malaria di Desa Buaran Kecamatan Mayong Kabupaten Jepara. Semarang : FKM UNDIP.

Depkes R.I. 1983. Pemberantasan Malaria 2. Jakarta : Ditjen Pencegahan dan Pemberantasan Penyakit Menular.

Depkes R.I. 1999. Modul Epidemiologi Malaria 1. Jakarta : Ditjen PPM \& PLP.

Depkes R.I. 2001. Pedoman Ekologi dan Aspek Perilaku Vektor. Jakarta : Ditjen PPM \& PL.

Depkes R.I, 2003. Survei Dinamika Penularan Malaria. Jakarta : Ditjen PPM \& PL.

Erdinal, dkk. 2006. Faktor-faktor yang berhubungan dengan kejadian malaria di Kecamatan Kampar kiri Tengah Kabupaten Kampar tahun 2005-2006. MAKARA Kesehatan, Vol.10, No.2. (online), (http://repository.ui.ac.id/contents/k oleksi/2/51b6c862124e72f9bcd6bb 492059d6605b831d5f.pdf, diakses tanggal 20 Desember 2011).

Friaraiyatini, dkk. 2005. Pengaruh Lingkungan dan Perilaku Masyarakat terhadap Kejadian Malaria di Kabupaten Barito Selatan Provinsi Kalimantan Tengah. Jurnal Kesehatan Lingkungan Vol. 2, No. 2 Januari 2006: 121-128. (online), (www.jurnal.unair.ac.id. diakses tanggal 20 Desember 2011)

Gandahusada, S. 2006. Parasitologi Kedokteran. Fakultas Kedokteran Universitas Indonesia. Jakarta : FK UI.

Harijanto. 2000. Malaria (Epidemiologi, patogenesis, Manifestasi Klinis, dan penanganan). Jakarta : Kedokteran EGC.

Harijanto, dkk. 2009. Malaria Dari Molekuler Ke Klinis. Jakarta : Kedokteran EGC.

Harmendo. 2008. Faktor Risiko Kejadian Malaria di Wilyah Kerja Puskesmas Kenanga Kecamatan Sungailiat Kabupaten Bangka Provinsi Kepulauan Bangka Belitung. (Tesis Tidak Dipublikasikan). Semarang : Program Pasca sarjana Universitas Dipenogoro. 
Hasan, Boesri., dkk. 1988. Respon Masyarakat terhadap Penggunaan Kelambu Berinsektisida dalam Rangka Pemberantasan Malaria di Desa Tarahan Lampung Selatan. Semarang : Majalah Kedokteran Diponegoro.

Husin, Hasan. 2007. Analisis Faktor Risiko Kejadian Malaria di Puskesmas Sukamerindu Kecamatan Sungai Serut Kota Bengkulu Propinsi Bengkulu. (Tesis Dipublikasikan). (http://eprints.undip.ac.id/17530/1/ Hasan_Husin.pdf). Semarang : Program Pascasarjana Universitas Diponegoro.

Jambulingan, et.al. 2007. Insectisida treated mosquito nets for malaria control in India-experience from a tribal area on operational feasibility and uptake. Mem. Inst. Oswaldo Cruz vo. 103 no. 2. (online), (http://dx.doi.org/10.1590/S007402762008005000009 . diakses tanggal 24 Desember 2011).

Achmadi, Umar. 2008. Manajemen Penyakit Berbasis Wilayah, Seri Desentralisasi Kesehatan Masyarakat. Jakarta : Universitas Indonesia.

Anies. 2006. Manajemen Berbasis Lingkungan - Solusi Mencegah dan Menanggulangi Penyakit Menular. Hal. 94,97-98. Jakarta : PT Elex Media Komputindo.

Arsin, Arsunan. 2004. Analisis Epidemiologi Terhadap Kejadian Malaria Pada Daerah Kepulauan di Kabupaten Pangkajene Kepulauan Propvinsi Sulawesi Selatan. (Disertasi tidak dipublikasikan) Makassar : Program Pascasarjana FKM Unhas

Basuki, B. 2000. Aplikasi Metode Kasus Kontrol. Jakarta : Fakultas Kedokteran Universitas Indonesia.

Bradley, dkk. 1986. Bed-nets (MosquitoNets) and Morbidity From Malaria, Journal The Lancent, Volume 328, p.204-207.

(online), (http://www.thelancet.com/journals lancet/article/PIIS01406736\%2886\%2992500-6/abstract, diakses tanggal 20 Desember 2011).

CDC. Life Cycle of The Malaria Parasite. (online) (http://www.encarta.msn.com), diakses tanggal 20 Desember 2011.

Kementrian Kesehatan R.I. 2011. Epidemiologi Malaria di Indonesia. (online),(http://www.depkes.go.id/d ownloads/publikasi/buletin/BULET IN\%20MALARIA.pdf, diakses tanggal 10 Desember 2012).

Keputusan Menteri Kesehatan RepubIik Indonesia Nomor 293 tahun 2009.

Tentang Program Eliminasi Malaria di Indonesia. Jakarta : Kementrian Kesehatan RI.

Kurniawan, Jeppry. 2008. Analisis Faktor Risiko Lingkungan dan Perilaku Terhadap Kejadian Malaria di Kabupaten Asmat Tahun 2008. (Tesis dipublikasikan). (http://eprints.undip.ac.id/8857/).

Semarang : Program Pasca Sarjana Universitas Diponegoro.

Lukwa N, Chiwade T. 2008. Lack of insecticidal effect of mosquito coils containing either metofluthrin or esbiothrin on Anopheles gambiae sensu lato mosquitoes. Trop Biomed,25(3):191-5. (online), (http://www.msptm.org/files/191_195_Nzira_Lukwa.pdf, diakses tanggal 24 Desember 2011).

Loka Litbang P2B2 Ciamis. 2006. Laporan Hasil Survey Entomology Pasca Tsunami di Pesisir Pantai Selatan Kabupaten Ciamis. Pangandaran: Badan Penelitian dan Pengembangan Kesehatan RI.

Margono, SS. 2003. Parasitologi Kedokteran. Jakarta : CV Gaya Baru.

Mukono, MJ., 2002. Epidemiologi Lingkungan, cetakan I. Surabaya : Airlangga.

Munif, Amrul dan Imron, Moch. 2010. Panduan Pengamatan Nyamuk Vektor Malaria. Jakarta : CV Sagung Seto,.

Muslim, M., 2009. Parasitologi Untuk Keperawatan. Hal 58-59. Jakarta : Kedokteran EGC

Natadisastra, dkk., 2009. Parasitologi Kedokteran: Ditinjau dari Organ Tubuh yang diserang. Hal. 214-216. Jakarta : Kedokteran EGC. 
Notoatmojo, S., 2010. Metodologi Penelitian Kesehatan, Edisi Revisi. Jakarta : Rineka Cipta.

NSW Arbovirus Surveilance \& Vector Monitoring Program. 2011. (online) (http://www.arbovirus.health.nsw.g ov.au/mosquit/photos/mosquitophot os_anopheles.htm), diakses tanggal 20 Desember 2011.
Ntonifor, Nelson N, et.al. (2006). Environmental Factors Affecting Malaria Parasite Prevalence in Rural Bolifamba, South-West Cameroon. Afircan Journal of Health Sciences, Vol. 13, No. 1-2 January-June 2006. (Online) (http://www.bioline.org.br/pdf?jh06 007, diakses 12 April 2012). 